\title{
Correction to: Nurture is above nature: nursery experience determines habitat preference of red sea bream Pagrus major juveniles
}

\author{
Kohji Takahashi $^{1,2} \cdot$ Reiji Masuda $^{1}$
}

Published online: 20 December 2019

(c) The Author(s) 2019

\section{Correction to: Journal of Ethology (2019) 37:317-323 https://doi.org/10.1007/s10164-019-00605-6}

The article Nurture is above nature: nursery experience determines habitat preference of red sea bream Pagrus major juveniles, written by Kohji Takahashi and Reiji Masuda, was originally published Online First without Open Access. After publication in volume 37, issue 3, page 317-323 the author decided to opt for Open Choice and to make the article an Open Access publication. Therefore, the copyright of the article has been changed to $(\odot$ The Author(s) 2019 and the article is forthwith distributed under the terms of the Creative Commons Attribution 4.0 International License (http:// creativecommons.org/licenses/by/4.0/), which permits use, duplication, adaptation, distribution and reproduction in any medium or format, as long as you give appropriate credit to the original author(s) and the source, provide a link to the
Creative Commons license, and indicate if changes were made.

The original article has been corrected.

Open Access This article is licensed under a Creative Commons Attribution 4.0 International License, which permits use, sharing, adaptation, distribution and reproduction in any medium or format, as long as you give appropriate credit to the original author(s) and the source, provide a link to the Creative Commons licence, and indicate if changes were made. The images or other third party material in this article are included in the article's Creative Commons licence, unless indicated otherwise in a credit line to the material. If material is not included in the article's Creative Commons licence and your intended use is not permitted by statutory regulation or exceeds the permitted use, you will need to obtain permission directly from the copyright holder. To view a copy of this licence, visit http://creativecommons.org/licenses/by/4.0/.

The original article can be found online at https://doi.org/10.1007/ s10164-019-00605-6.

Kohji Takahashi

ta.kohji@gmail.com

1 Maizuru Fisheries Research Station, Kyoto University, Nagahama, Maizuru, Kyoto 625-0086, Japan

2 Present Address: Department of Biology, Keio University, 4-1-1 Hiyoshi, Kouhoku, Yokohama 223-8521, Japan 